\title{
細径鋼管により地盤補強した基礎の沈下挙動とその予測法
}

\author{
第 1 報＼cjkstart基礎の沈下挙動と補強地盤の支持力特性
}

\section{FOUNDATION SETTLEMENT ON THE REINFORCED GROUND BY SLENDER PIPES AND ITS PREDICTION METHOD}

Patr 1 Foundation settlement and bearing capacity of reinforced ground

\author{
若命善雄*，榎並 昭**，真島正 人***，長尾俊昌**** \\ Yoshio WAKAME, Akira ENAMI, Masato MAJIMA and Toshiaki NAGAO
}

\begin{abstract}
In order to study the foundation settlement and the bearing capacity of the ground reinforced by slender steel pipes, laboratory and in-situ vertical loading tests were conducted. The result can be summarized as follows .

The reinforcement of ground by pipes decreases the settlement of foundation and increases the bearing capacity of the ground. These effects are more remarkable when longer pipes are used, and when soil layer near the pipes end are harder than the surface layer. If pipes having the ultimate bearing capacity of $1.5 \mathrm{tf}$ or more per pipe are installed such that there is two pipes in every area interval of $45 \times 60 \mathrm{~cm}$, the reinforced ground having long term allowable bearing capacity of $5 \mathrm{tf} / \mathrm{m}^{2}$ or higher can be obtained. However, the long term allowable bearing capacity of a reinforced ground can't be obtained by simply summing up the long term allowable bearing capacity of the pipes and of the unreinforced ground.
\end{abstract}

Keywords: slender steel pile, foundation settlement, reinforced ground, bearing capacity, model test, in-situ loading test 細径銅管，基礎の沈下，補強地盤，支持力，模型実験，原位置载荷実験

\section{1.まえがき}

軟弱地盤上に建設される戸建て住宅の沈下障害を防止 するため、これまで杭基礎をはじめとして、井桁基礎、 表層混合処理、柱状混合処理、こま型基礎など数多くの 基礎工法や地盤改良工法が考案され1),2)、模型実験や原位. 置実験などによって得られた基礎の沈下挙動や支持力特 性についても幾つか報告されている33,4),5)。

筆者らは、基礎スラブ直下の地盤中に直径約 $5 \mathrm{~cm}$ の細 径鋼管を密に設置して地酎力増加を図る、小規模建物用 の基礎地盤補強工法を開発した。

この工法については、昭和63年に建築センター評定を 取得しの、既に400棟以上の住宅に適用しているが、開発 過程において室内模型実験、原位置実験によりその効果 を確認した。本論文では、工法の概要、模型載荷実験と 原位置載荷実験によって得られた基礎の沈下挙動と補強 地盤の支持力特性、および、補強地盤の長期許容支持力 推定法について述べる。

\section{2. 工法の概要}

本工法は、許容支持力度 $3 \mathrm{tf} / \mathrm{m}^{2}$ 程度の地盤上の布基礎直
下に、最大長さ $5.5 \mathrm{~m}$ の細径鋼管（以下鋼管とよぶ）を40 〜 60cmの間隔で貫入し、地盤と鋼管の複合作用（地盤の 耐力十地盤と鋼管との周面摩擦力十鋼管先端支持力）に より地耐力を増加させ、 $3 \mathrm{tf} / \mathrm{m}^{2}$ 用の基礎に代って、 $5 \mathrm{tf} / \mathrm{m}^{2}$ 用の基礎を採用しようとするものである。表1に使用す る鋼管の仕様を、図1に代表的な適用事例を示す。

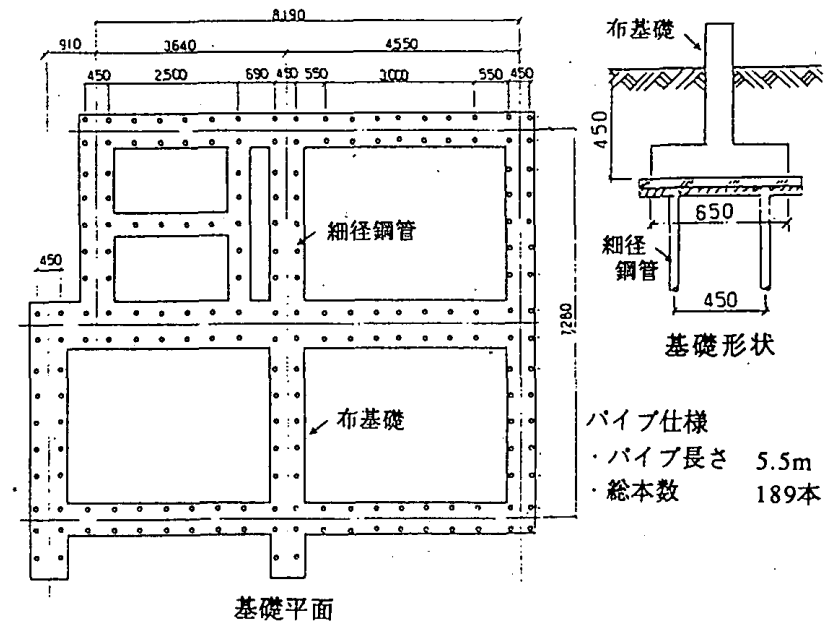

図1 代表的な適用事例
* 大成建設 (株) 技術研究所

** 日本大学理工学部建築学科 教授・工博

***大成建設 (株) 技術研究所 主任研究員

**** 大成建設 (株) 技術研究所 研究員
Technology Research Center, Taisei Corporation

Prof., Dept. of Architecture, Faculty of Science and Engineering, Nihon Univ., Dr. Eng.

Senior Research Eng., Technology Research Center, Taisei Corporation

Research Eng., Technology Research Center, Taisei Corporation 
基礎設計に当っては、まず建設地内でスウェーデン式 サウンディング試験を行う。その結果、鋼管の極限支持 力が1.5tf/本以上となる、下記 2 タイプの地盤である場合 のみ本工法を適用する。

1)地表面から媣さ $6 \mathrm{~m}$ までの範囲にWsw $100 \mathrm{kgf}$ 軟弱粘 性土層が $1 \mathrm{~m}$ 以上存在し、哚さ $6 \mathrm{~m}$ 以深には $\mathrm{N} \mathrm{sw} \geqq 40$ の 良好な土層が続いている地盤。この際、鋼管を N sw 40 の土層に $50 \mathrm{~cm}$ 以上貫入させる(図2(a)参照)。

2) $\mathrm{N} \mathrm{sw} \geq 40$ の土層の出現深度は $6 \mathrm{~m}$ 以深であるが、6 $\mathrm{m}$ 以 浅に表2に示す土層が存在する地盤。この際の鋼管長 さは $5.5 \mathrm{~m}$ とする(図2(b)参照)。

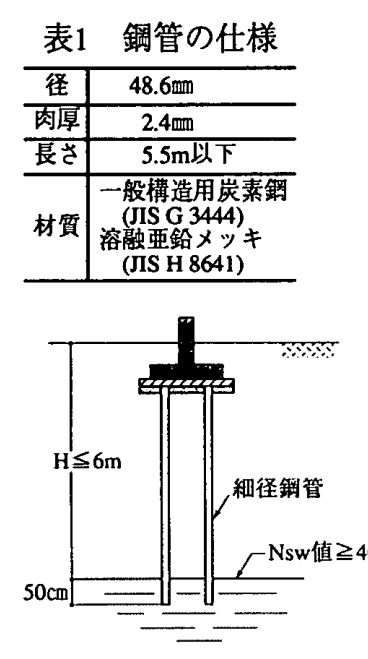

(a)
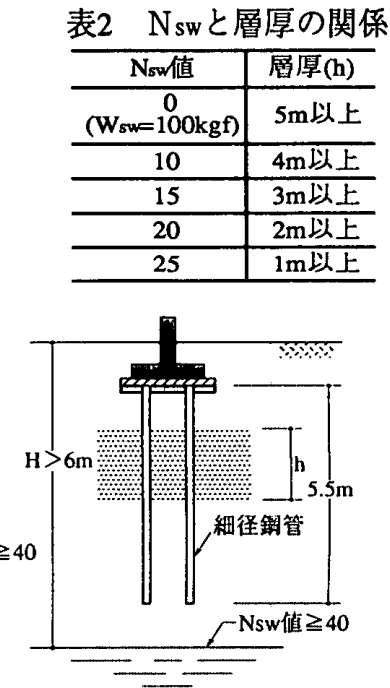

(b) 図2＼cjkstart本工法を適用する地盤

\section{3. 基礎の沈下挙動と㭪強地盤の支持力特性}

鋼管を貫入した地盤（以下補強地盤とよぶ）上に基䃈 スラブ (以下基礎とよぶ) を設置すると、図3に示すよ うな支持機構が形成される。すなわち、基礎を含む建物 重量は、基礎より直接地盤に伝達されるものと、鋼管を 介して地盤に伝達されるものの 2 経路で地盤に伝達され る。そして、鋼管周面と地盤との摩擦力と鋼管先端地盤 の支持力により基礎の沈下は隇少し、補強地盤の支持力 は見掛け上増加すると予想される。これらの効果を確認 するため、室内模型実験と原位置実験を行った7)。

\section{1 室内模型実験}

\section{1.1 実験概要}

均質な粘性土を圧密養生して作製した模型地盤中に、 前述の鋼管を模したアルミ製パイプを鉛直に埋設した 後、基礎を模した剖な載荷板を地表面に設け、これを重 錘により加力する方法によって載荷実験を行った。この 際、載荷板隅角部の沈下量を摺動抵抗型変位計、パイプ の軸力分布をひずみゲージにより計測し、パイプ長、地 盤強度、荷重度の違いが、載荷板の沈下挙動、補強地盤 の支持力特性に及ほす影響について調査した。
（1）模型地盤と土槽

地盤材には市販のカオリン粘土を使用した。模型地盤 は、この粘土を含水此 $120 \%$ まで加水混合してペースト 状にした後、土槽内に厚さ $1 \mathrm{~m}$ とるように詰め、0.2 kg $\mathrm{f} / \mathrm{cm}^{2} 、 ま た は 、 0.4 \mathrm{~kg} \mathrm{f} / \mathrm{cm}^{2}$ の荷重度で2ヶ月間圧密羑生して 作成した。試料土の物理的性質を表3に、試料土の圧密 特性を表4に示す。土槽の寸法は、幅 $1.2 \mathrm{~m} \times 2.0 \mathrm{~m}$ 、高さ $1.2 \mathrm{~m}$ である。この土槽は、図4に示すように、最大 4 室 まで仕切ることが可能で、側壁と底板は、圧密養生の際 に、地盤中の過剩間隙水圧が上下方向と水平方向より消 散できるような構造になっている。なお、実験時には、 壁内の水位は常に地盤表面とほほ同一レベルに保たれて いる。

表3 試料土の物理的性質

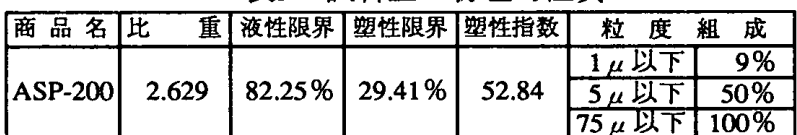

表4 試料土の圧密特性

\begin{tabular}{|c|c|c|c|c|c|}
\hline $\begin{array}{c}\text { 初期 間隌比 } \\
\mathrm{e}_{0}\end{array}$ & $\begin{array}{l}\text { 含 水 比 } \\
\omega_{0}(\%)\end{array}$ & $\begin{array}{c}\text { 圧 縮指 } \\
\mathrm{C} \text { c } \\
\end{array}$ & $\begin{array}{l}\text { 圧密荷重 } \\
\mathrm{Pc}\left(\mathrm{kgf} / \mathrm{cm}^{2}\right)\end{array}$ & $\begin{array}{l}\text { 体税圧樎保数 } \\
\mathrm{m} v\left(\mathrm{~cm}^{2} / \mathrm{kgf}\right)\end{array}$ & $\begin{array}{l}\text { 圧密 你 } \\
\mathrm{C}_{\mathrm{v}}\left(\mathrm{cm}^{2} / \mathrm{day}\right)\end{array}$ \\
\hline \multirow{2}{*}{3.15} & \multirow{2}{*}{120.0} & \multirow{2}{*}{0.58} & 0.2 & 0.35 & 93.3 \\
\hline & & & 0.4 & 0.17 & 90.4 \\
\hline
\end{tabular}

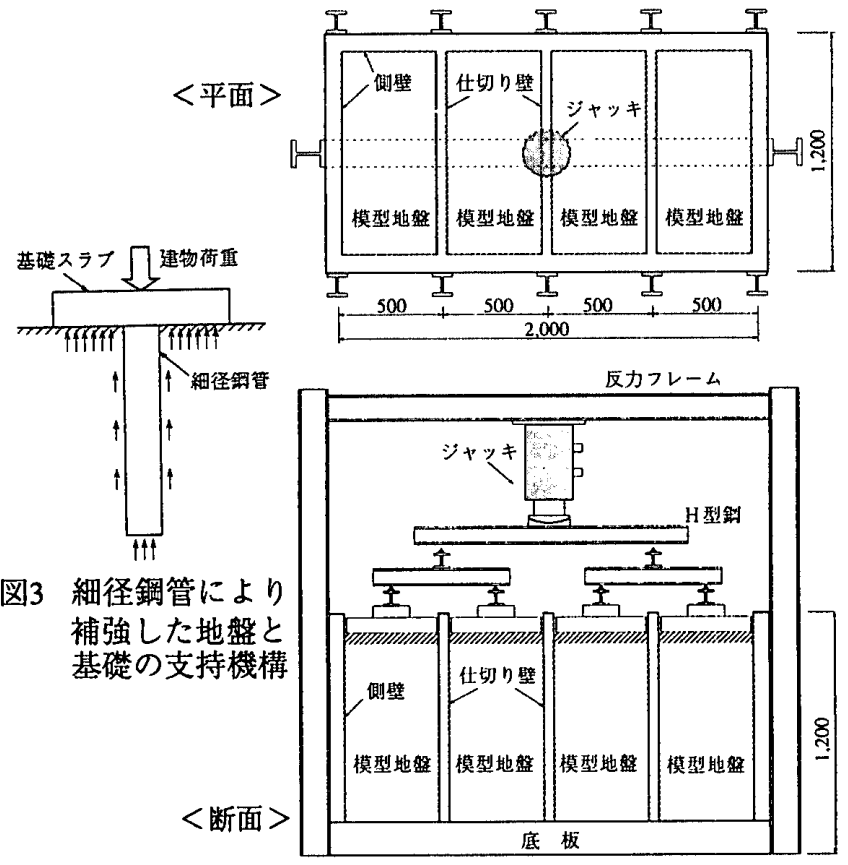

図4 土槽の平・断面図

(2) パイプの諸元と設置

アルミ製パイプ（以下パイルと呼ぶ）の寸法は、外径

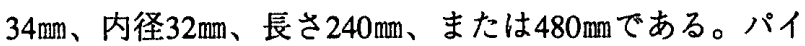
ル内面には、図5に示すようにひずみゲージが貼付され ている。パイルの設置は圧密荷重を載荷後45日目に行 い、直径34mmのケーシングを圧入しながら内部の土を オーガーにより排出し、所定の深度に達したらケーシン 


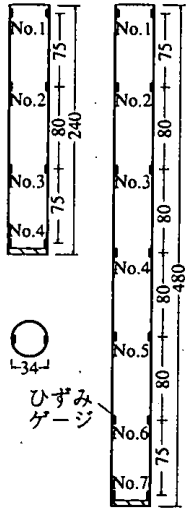

図5

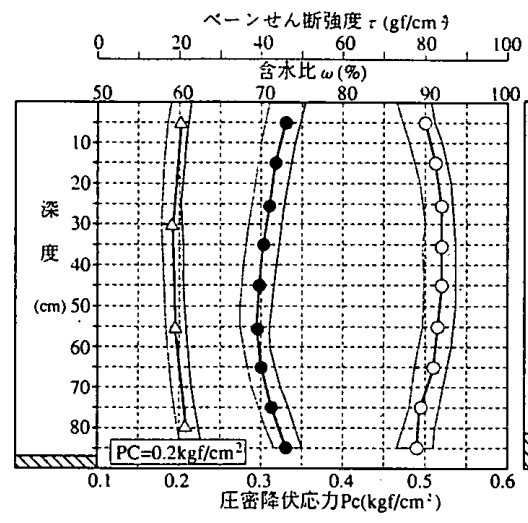

図7地盤物性值の深度方向分布

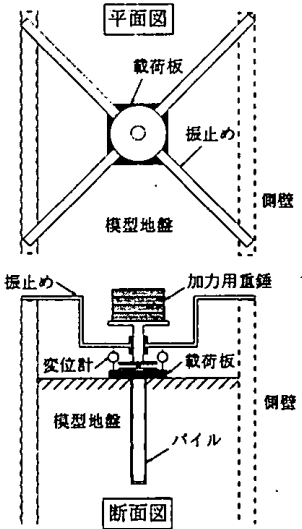

図6 載荷実験装置の 概要図

グを引き抜き、その孔にパイルを挿入する方法により 行った。パイル設置後、再び元の荷重で約15日間圧密盖 生してパイル周面の土の乱れの影響を少なくした後、載 荷実験を行った。

（3）載荷実験装置と載荷方法

載荷実験には、図6に示す装置を用いた。載荷は、 $0.025 \mathrm{~kg} \mathrm{f} / \mathrm{cm}^{2}$ の荷重増分で終局まで段階的に載荷（沈下量 が5分間に $5 / 100 \mathrm{~mm}$ 以となったら次の荷重段階に移行） する方法によって行った。なお、パイルのみの載荷実験 も実施しており、この際の載荷は $0.5 \mathrm{kgf} \sim 2 \mathrm{kgf}$ の荷重增 分で釉局まで段階的に加力する方式とした。

\section{(4) 実験の種類}

一連の実験では、圧密荷重（2種類：0.2,0.4 $\mathrm{kgf} / \mathrm{cm}^{2}$ ) パ イル本数 ( 3 種類: $0,1,2$ 本) 、載荷板寸法 ( 3 種類 : $0,10,20 \mathrm{~cm}$ 角）、パイル長（2 種類: $24,48 \mathrm{~cm}$ ) をパラメー タとし、合計12ケースの実験を行った。実験ケース名と 実験条件を表5に一括して示す。

表5 実験ケースと実験条件

\begin{tabular}{|c|c|c|c|c|c|}
\hline \multirow[b]{2}{*}{ 実験ケース名 } & \multicolumn{2}{|r|}{ 実 } & 伢 条 & 件 & \multirow[b]{2}{*}{ 載荷タイブ } \\
\hline & $\begin{array}{c}\text { 載荷板幅 } \\
(\mathrm{cm})\end{array}$ & パイル本数 & $\begin{array}{c}\text { パイル 長 } \\
(\mathrm{cm})\end{array}$ & $\begin{array}{c}\text { 压密荷重度 } \\
\left(\mathrm{kgf} / \mathrm{cm}^{2}\right)\end{array}$ & \\
\hline P-S-2 & $=$ & 1 & 24 & 0.2 & $\bar{A}$ \\
\hline P-L-2 & - & 1 & 48 & 0.2 & $\mathrm{~A}$ \\
\hline P-S-4 & - & 1 & 24 & 0.4 & $\bar{A}$ \\
\hline P.L-4 & - & 1 & 48 & 0.4 & $\bar{A}$ \\
\hline R1-S-2 & 10 & 1 & 24 & 0.2 & $\bar{B}$ \\
\hline R1-L-2 & 10 & 1 & 48 & 0.2 & $\mathrm{~B}$ \\
\hline R1-S-4 & 10 & 1 & 24 & 0.4 & $B$ \\
\hline R1-L-4 & 10 & 1 & 48 & 0.4 & $\bar{B}$ \\
\hline S-10-2 & 10 & 0 & - & 0.2 & $\mathrm{C}$ \\
\hline S-10-4 & 10 & 0 & - & 0.4 & $\mathrm{C}$ \\
\hline R2-L-4 & 20 & 2 & 48 & 0.4 & $B$ \\
\hline S-20-4 & 20 & 0 & - & 0.4 & $\bar{C}$ \\
\hline
\end{tabular}

$\mathrm{A}$ ：パイルのみ, $\mathrm{B}:$ パイル+载荷板, $\mathrm{C} ：$ 載荷板のみ

\section{（5）圧密終了時の地盤物性}

2 種類の荷重度PC $\left(0.2 \mathrm{~kg} \mathrm{f} / \mathrm{cm}^{2} 、 0.4 \mathrm{kgf} / \mathrm{cm}^{2}\right)$. で60日間 圧密養生した後の最終的な圧密沈下量は前者で約 $10 \mathrm{~cm}$ 、 後者で的 $16 \mathrm{~cm}$ となた。この地盤のほほ中央部から深さ $5 \mathrm{~cm} こ ゙ と に$ 試料を探取し、含水比試験、圧密試験を実施 すると共に、土槽内でベーンせん断試験を実施した。図

7に各物性值の深度方向分布を示すが、実験ケースごと に、最大 $10 \%$ 程度の物性值のばらつきが認められた。

3. 1 . 2 載荷実験結果

\section{（1）荷重一沈下量関係}

図8に載荷荷重と各荷重段階における載荷板の最終沈 下量（隅角部 4 点の平均値）との関係を示す。同図中に は、タイプAの結果も示してある。図9に、タイプ B,C の載荷板の沈下量を $\mathrm{SB}_{\mathrm{B}, \mathrm{SC}}$ して、パイルによる載荷板 の沈下低減率（1-SB/SC）と荷重度との関係を示す。ま た、表6に、極限荷重Pu、 $\log P-\operatorname{logS}$ 関係より求めた降伏荷 重Py、タイプCに対するタイプ A, BのPuの比( $\mathrm{PuA}_{\mathrm{u}}$ /

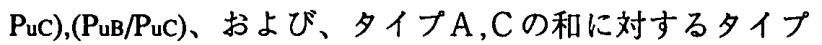
$\mathrm{B}$ のPyの比(PyB/PyAC)とPuの比(PuB/PuAC)を示す。ただし、

Puは、タイプAについては最大荷重、タイプ B,Cについ ては載荷板の沈下量 $2 \mathrm{~cm}$ に対応する荷重とした。

これらの図表より、以下の点が明らかとなった。 1)パイルを設置することにより載荷板の沈下量は減少 し、補強地盤の支持力は増加する。

2)パイル設置による沈下低減率（1-SB/SC）、支持力増加 率(PuB/PuC)は、夕イプCの極限荷重に対する夕イプAの 極限荷重の比(PuA/Puc)が大きいほど高くなる。すなわ ち、地盤条件が同一の場合には、パイルが長く、パイル 1 本の支配面積が小さいほど沈下低減率、支持力増加率 は高くなる。

3)パイルによる沈下低減率は、荷重の増加および沈下量 の進行とともに高くなる。

4)地盤強度が異なっても沈下低減率、支持力増加率に明 確な差異は認められない。

5)極限荷重時におけるタイプA，Cの荷重の和に対する夕 イプ Bの荷重の比 $(\mathrm{PuB} / \mathrm{PuAC})$ は0.90〜0.97の值を示すのに 対し、降伏荷重時における荷重の比(PyB/PyAC)は0.78〜 0.85 の值を示し、いずれのケースも(Рyв/PyAC)より(PuB/ PuAC)の方が大きくなっている。

(2) パイルの軸力分布と摩擦力分布

図10に実験ヶースP-L-4（タ.イプA）とR1-L-4（タイプ B）の各荷重段階におけるパイルの軸力分布を、図11に 

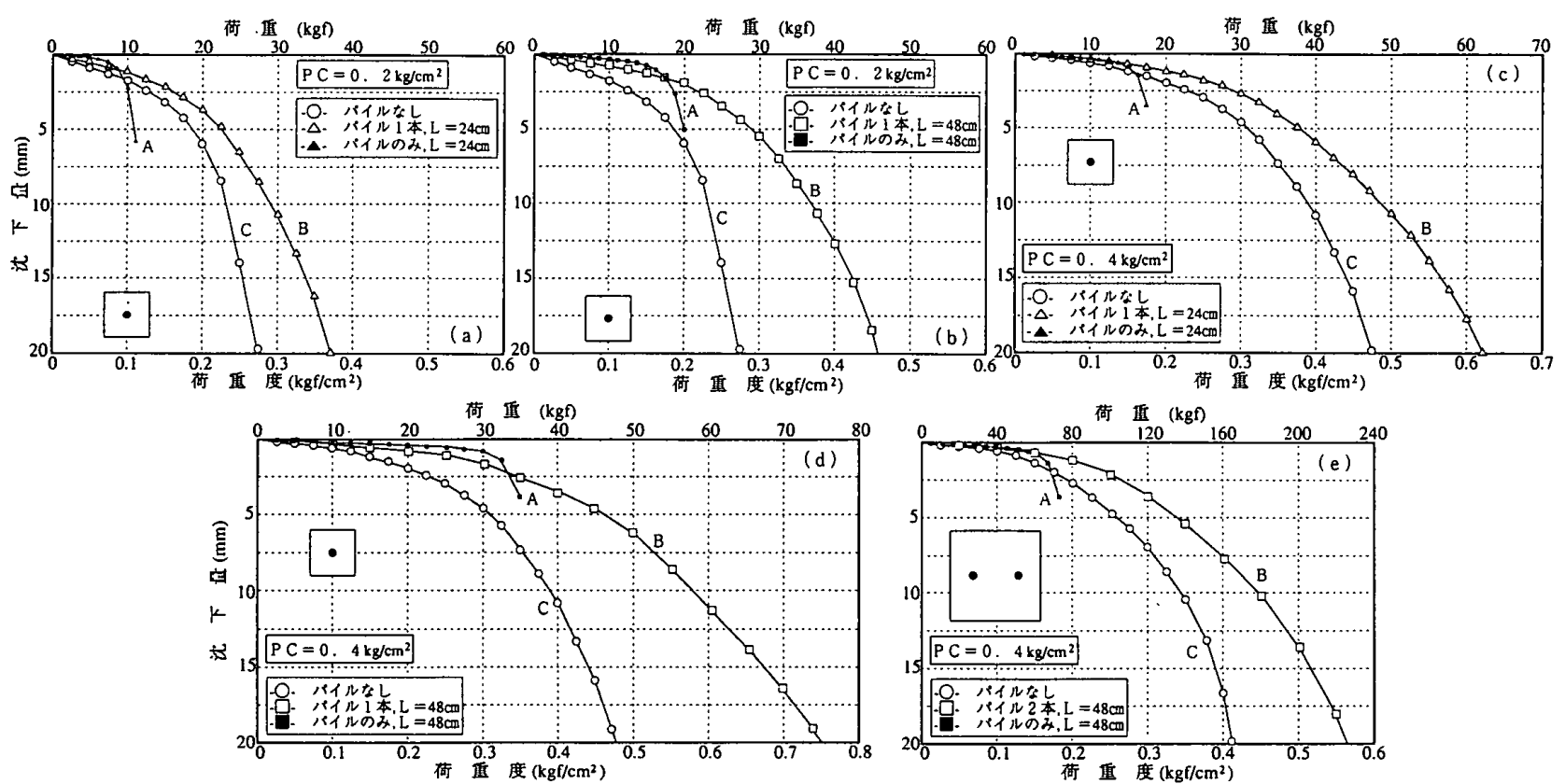

図8 載荷板の荷重一沈下量関係

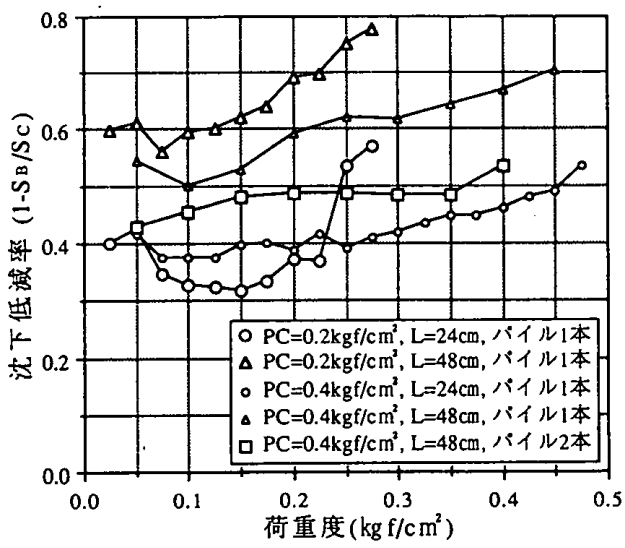

図9 沈下低減率一荷重度関係

表6 Pu,Py,(PuA/PuC),(Puв/Puc),(Рув/PyAC), および,(PuB/PuAC)の比較表

\begin{tabular}{|c|c|c|c|c|c|c|}
\hline 英锄ヶース名 & $\begin{array}{c}P_{u} \\
\left(\mathrm{~kg} / / \mathrm{cm}^{2}\right)\end{array}$ & $\begin{array}{c}\mathrm{Py} \\
\left(\mathrm{kgf} / / \mathrm{c}^{2}\right)\end{array}$ & $\begin{array}{l}\text { Pus } \\
\text { Puc }\end{array}$ & $\begin{array}{l}\text { PuB } \\
\text { Puc }\end{array}$ & $\begin{array}{l}\text { PyB } \\
\text { PyAC }\end{array}$ & $\begin{array}{l}\text { PuB } \\
\text { PuAC } \\
\end{array}$ \\
\hline P.S-2 & 11.5 & 9.0 & & & & \\
\hline P-L-2 & 20.5 & 18.2 & & & & \\
\hline S-10-2 & 27.5 & 17.7 & & & & \\
\hline RI-S-2 & 36.5 & 21.6 & 0.42 & 1.33 & 0.81 & 0.94 \\
\hline R1-L-2 & 46.0 & 30.2 & 0.75 & 1.67 & 0.84 & 0.96 \\
\hline P-S-4 & 18.0 & 15.2 & & & & \\
\hline $\mathrm{P}=\mathrm{L}-4$ & 36.0 & 31.2 & & & & \\
\hline S-10-4 & 46.5 & 29.6 & & & & $\therefore$ \\
\hline R1-S-4 & 62.5 & 39.1 & 0.39 & 1.34 & 0.85 & 0.97 \\
\hline R1-L-4 & 74.0 & 48.2 & 0.77 & 1.60 & 0.78 & 0.90 \\
\hline S-20-4 & 164.0 & 98.2 & & & & \\
\hline R2-L-4 & 223.0 & 130.8 & 0.44 & 1.36 & 0.82 & 0.95 \\
\hline
\end{tabular}

代表的な荷重段階でのパイル周面の単位長さ当たり平均 摩擦力分布を示す。また、図12にパイル頭部の軸力に対 するパイル先端部の軸力の比率（荷重先端到達率）とパ イル頭部の軸力との関係を示す。

これらの図より、以下の点が明らかとなった。 1)タイプAとタイプ Bの軸力分布、摩擦力分布には大き な違いが認められる。すなわち、前者では全ての荷重領
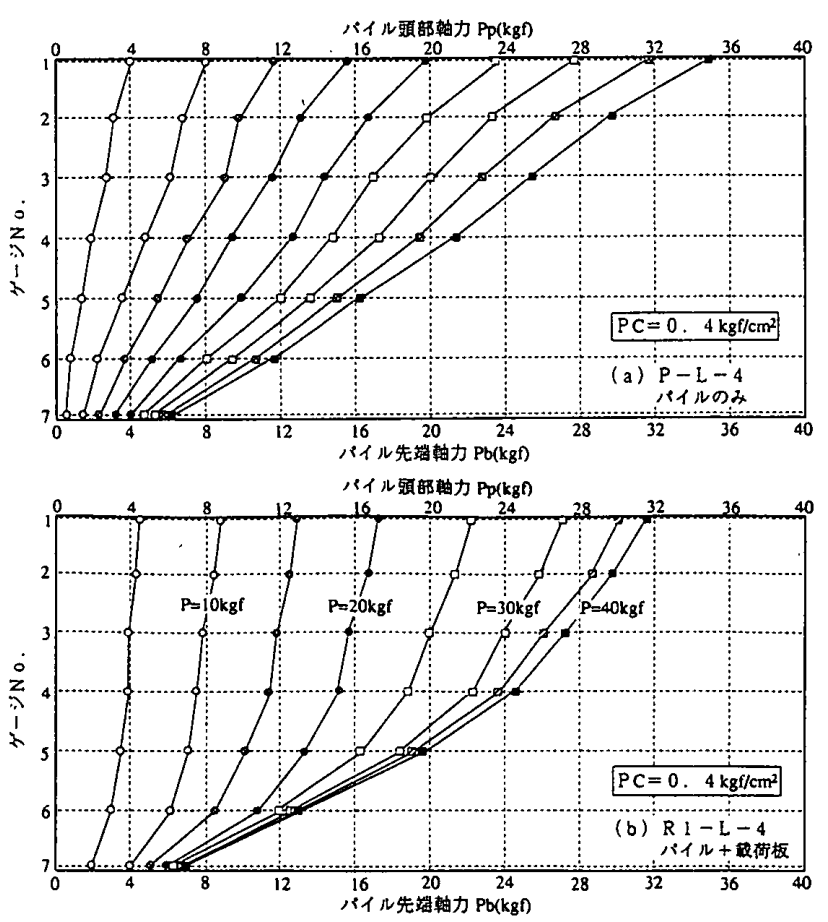

図10 パイル軸力分布

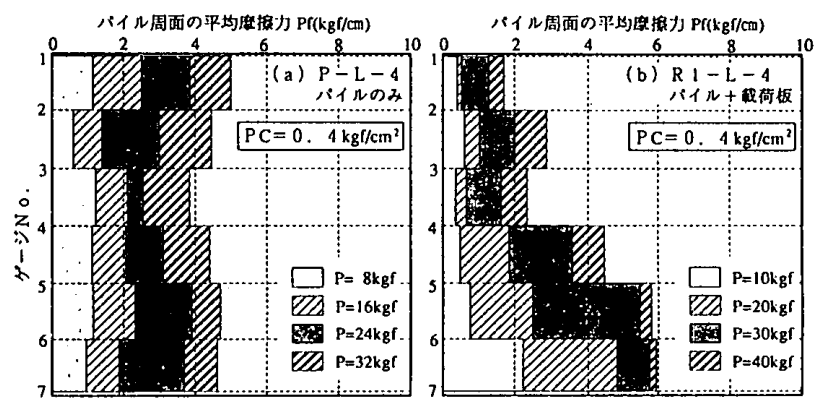

図11 パイル周面の平均摩擦力分布 

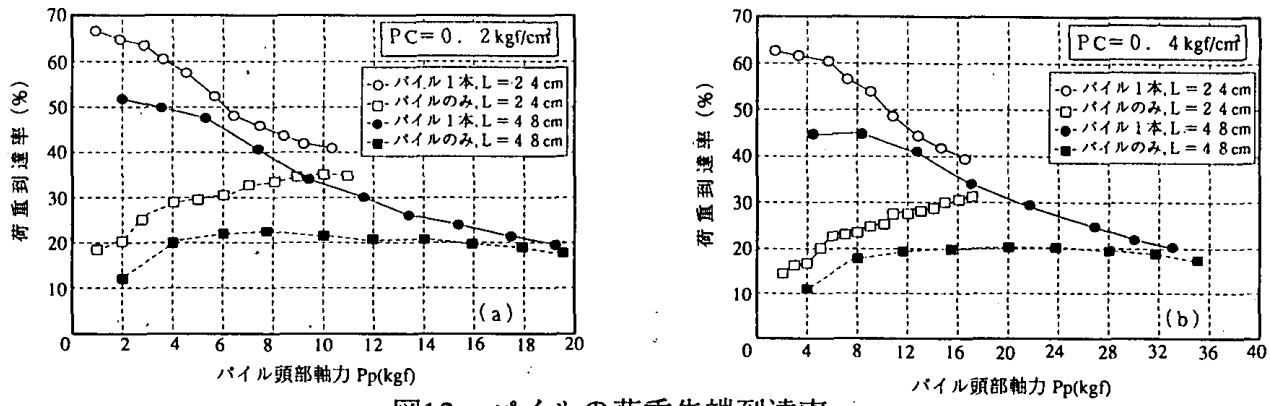

図12 パイルの荷重先端到達率
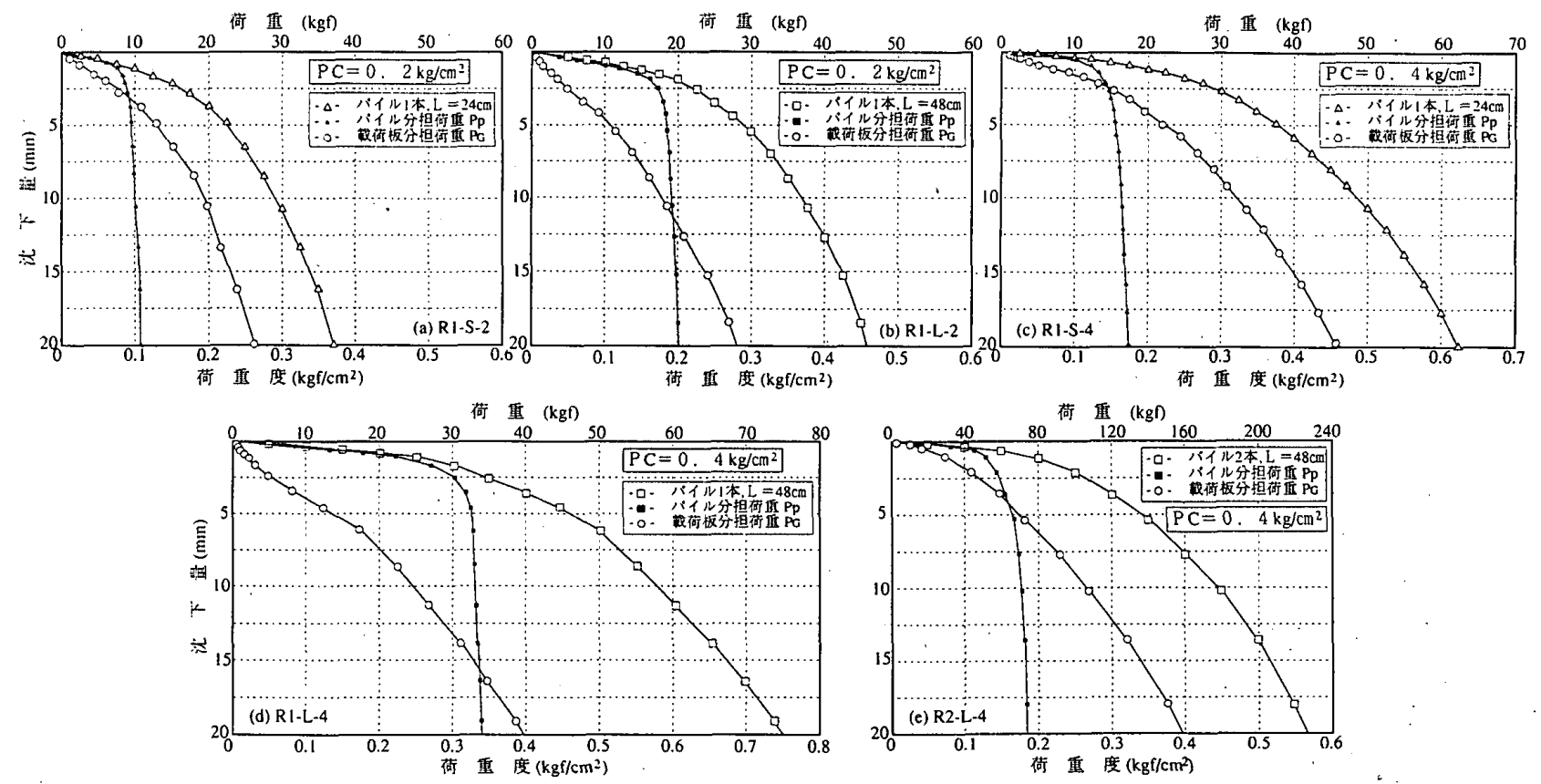

図13 $\mathrm{P}, \mathrm{Pp}_{\mathrm{p}}, \mathrm{P}_{\mathrm{G}}$-沈下量関係

域でほほ直線的な軸力分布（一様な摩擦力分布）になる のに対し、後者ではパイル先端に近い位置ほど軸力低下 量が大きくなる（摩擦力が大きい）。

2)パイルが長いほど荷重先端到達率は減少する。

3)タイプAよりタイプ Bの方が荷重先端到達率は大き く、前者では荷重度の增加とともに僅かに增加するか一 定となるのに対し、後者では荷重度の增加に伴い減少 し、最終的に両者はほほ同じ値に収れんする。

（3）地盤とパイルとの荷重分担

図13に、タイブBについて、載荷荷重 $\mathrm{P}$ 、パイル頭部 の軸力 $\mathrm{P}_{\mathrm{p}}$ 、地盤が直接分担する荷重 $\mathrm{P} \mathrm{G}_{\mathrm{G}}\left(=\mathrm{P}-\mathrm{P}_{\mathrm{p}}\right)$ と 沈下量との関係を示す。また、図 14 に $\mathrm{P} / \mathrm{PG}_{\mathrm{g}}$ （荷重分担

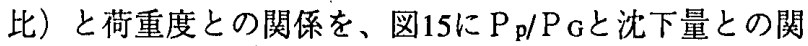
係を示す。これらの図より、タイプBの実験について以 下の点が明らかとなった。

1)地盤が直接分担する荷重 $\mathrm{PG}$ Gよパイルが分担する荷 重 $\mathrm{P}_{\mathrm{p}}$ の方がより小さな沈下量で降伏状態に達し、 $\mathrm{P}_{\mathrm{p}}$ が 降伏した以降においては、增分荷重の大部分を地盤が直 接分担する。

2)パイル頭部の軸力 $\mathrm{P}_{\mathrm{p}}$ は、図8中に示したタイプAの降 伏荷重より僅かに小さな荷重で降伏状態に達する。すな

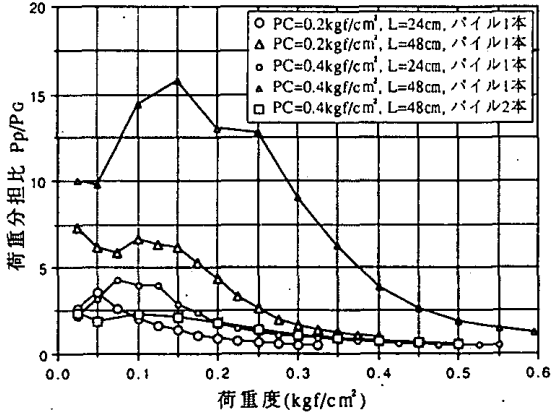

図14 荷重分担比と荷重度との関係

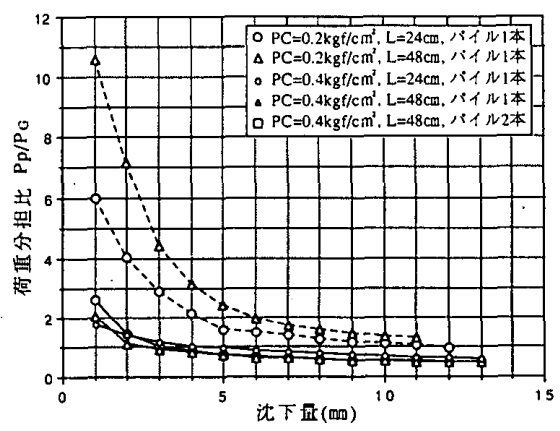

図15荷重分担比と沈下量との関係 
わち、タイプAのパイルよりタイプ Bのパイルの方が僅 かに小さな荷重で降伏状態に達する。ただし、両者の極 限荷重はほほ一致する。

3)荷重および沈下量の増加に伴い荷重分担比は低下し、 一定值に収れんする。この一定值は、タイプ A，Cの極 限荷重の比(PuA/PuC)にほほ相当している。 4)(PuA/Puc)が大きいほど、同一荷重レベル・沈下レベル での荷重分担比も大きくなる傾向を示す。

\section{1.3 実験結果に対する考察}

（1）載荷板の沈下性状と地盤の支持力

摩擦杭と直接基䃈を併用することにより、構造物の沈 下量を抑制するという考え方やその効果については既に 報告されている89,9),10)。したがって、パイルを設置するこ とにより載荷板の沈下量が低下する現象は事前に予想さ れた結果であるが、今回の実験により、沈下抑制効果だ けでなく補強地盤の支持力が増加する効果をも期待で き、しかも、タイプ A,Cの極限荷重の比(PuA/Puc)が大き いほど、両効果が顕著であることが確認できた。した がって、地盤条件が同一の場合には、パイルが長く、パ イル1本の支配面積が小さいほど、パイル設置の効果が 増加する。逆に、地盤条件が異なる場合でも、(PuA/Puc) に大きな違いがなければパイル設置の効果に顕著な差は 生じない。パイルの条件が同一で、 $\mathrm{PC}=0.2 \mathrm{~kg} \mathrm{f} / \mathrm{cm}^{2}$ と 0.4 $\mathrm{kgf} / \mathrm{cm}^{2}$ の地盤のパイル設置効果に顕著な差が認められな いのは、(PuA/Puc)に大きな違いがなかったことに起因し ていると考えられる。

一方、極限荷重時におけるタイプ A，Cの荷重の和に 対するタイプ $\mathrm{B}$ の荷重の比( $(\mathrm{PuB} / \mathrm{PuAC})$ が $0.90 \sim 0.97$ の範囲 となる（1に極めて近い）こと、タイプBが極限状態に 達する荷重レベル以前にパイルは既に極限状態に達し、 極限状態でのパイルの分担荷重がタイプAの極限荷重P に極めて近いこと、パイルと地盤との荷重分担比は荷重 （または沈下量）の増加とともに各々の極限荷重の比に 収束すること、土質性状に $10 \%$ 程度のばらつきがあった こと、更には、図8の沈下曲線より沈下量 $2 \mathrm{~cm}$ 以降も載荷 を継続すれば(PuB/PuAC)は若干增加すると予想されること など考慮すると、補強地盤の極限支持力度 q rdを、未補 強地盤の極限支持力度 $q$ 、、パイル 1 本の極限支持力 Pd、パイル1本数の支配面積 A を用い、式(1)によって近 似することが可能と考えられる。

$$
\mathrm{q} \mathrm{rd}_{\mathrm{d}}=\mathrm{q}_{\mathrm{d}}+\mathrm{Pd}_{\mathrm{d}} \mathrm{A}
$$

これに対し、タイプ A,Cの降伏荷重の合計值に対す るタイプ Bの降伏荷重の比(PyB/PyAC)は1よりかなり小さ なの值を示す。したがって、補強地盤の降伏荷重を未補 強地盤とパイル各々の降伏荷重の和によって表すことは できない。これは、図8から明らかなように、降伏荷重

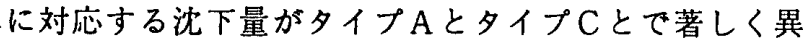
なっていることに起因している。以上のことから、補強
地盤の許容支持力度については、地盤とパイルの各々の 極限支持力度または降伏荷重度を同一の安全率で除して 算定するより、各々を異なった安全率で除して算定する のが適当と考えられる。

（2）パイルの軸力（摩擦力）分布

タイプAでは深さ方向に対しほほ值線的な軸力分布 (摩擦力一定) となるのに対し、タイプ Bではパイル先 端に近い位置ほど軸力の減少量（摩擦力）が大きくな る。タイプ Bのパイルの軸力分布形状は、渡井らが奏施 した摩擦杭を併用した直接基礎に対する聅測結果”と良 い対応を示している。また、パイルの何重先端到達率に については、タイプAでは荷重が増加しても大きな違い は認められないが、タイブBでは荷重の増加とともに隇 少し、最終的に前者の值に収れんする。この原因は、地 盤とパイルとの相対変位が前者では深さ方向でほほ一定 となるのに対し、後者ではパイル先端ほど大きく、摩擦 力もパイル先端に近い位置ほど早い時期に降伏するため と考えられる。図16と図17は、これらの関係を摸式的に 示したものである。図16(a)はパイルの鉛直変位分布、同 図(b)は地盤の鉛直分布を表しており、タイブAでは(a)が 地盤とパイルとの相対変位量となるが、タイプBでは (a),(b)の差、すなわち、(c)がパイルと地盤との相対変位 量となる。この相対変位量の違いにより、再者の摩擦力 分布には図17(a),(b)のような違いが生じることになる。

以上のことから、以下2項目が推察される。

1）タイプAとタイプ Bのパイルとでは、同一沈下量を 生じたときの荷重は、摩擦力がパイル全長において同程 度に発揮されるタイプAの方が当然大きくなるが、極限

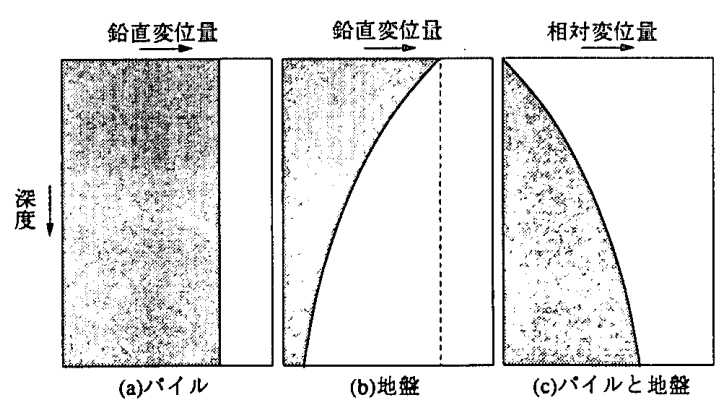

図16 鉛直変位量と相対変位

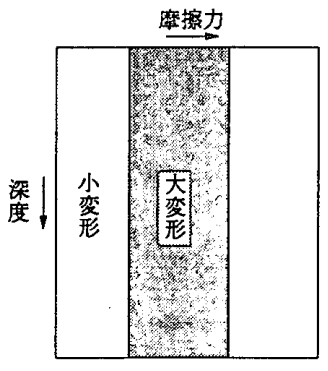

(a)パイルのみ

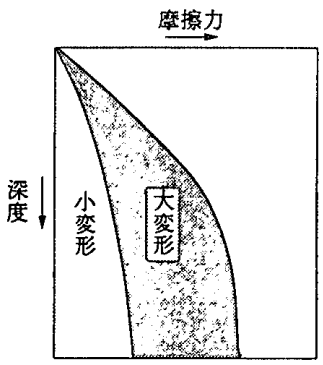

(b)バイル十载荷板
図17 パイルの摩擦力分布の比較（均一地盤） 
まで載荷すればタイプBのパイルの分担荷重はタイプA のパイルの極限支持力にほほ収れんする。

2）パイルによる載荷板の沈下低減効果は、載渮板に作 用した荷重の一部がパイルによって分担され、この分担 荷重がパイル周面摩擦力とパイル先端の反力として地盤 に伝達される祭に生じる現象である。すなわち、載荷板 底面とパイルから地盤へ荷重が伝達される位置までの間 の地中応力が末補強地盤より補強地盤の方が小さくなる ため、この間の地盤の沈下量が減少することによって生 ビる。また、タイブBではパイル先端部に近い位置ほど パイルと地盤との相対変位量が大きくなり、摩擦力が有 効に発揮される。したがって、パイルが長いほど、ま た、載荷板直下よりパイル先端付近の地盤が硬いほどパ イルから地盤への荷重伝達位置が深くなり、沈下低減効 果は增大する。

（3）地盤とパイルとの荷重分担

タイプBの載荷板とパイルとの荷重分担比 $\mathrm{N}(=\mathrm{P} / \mathrm{PG})$ は荷重レベルによって大きく異なり、パイルが降伏する 荷重付近を境界として徐々に低下し、最終的には一定値 に収れんする。Nが荷重度の増加とともに低下する現象 は石灰パイルによる複合地盤の載荷試験12にによっても確 認されていることから、パイル状に改良または補強した 複合地盤に共通した現象と考えられる。一方、この一定 值を $\mathrm{N}_{d}$ とすれば、表6、図13〜図15、および、パイルの 分担する荷重が最終的にはパイルのみの極限支持力に収 れんすると予想されることから、 $\mathrm{N}$ dを未補強地盤の極

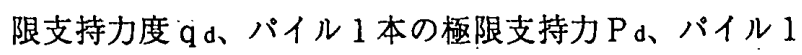
本数の支配面積 $\mathrm{A}$ を用い、式(2)によって近似すること が可能と考えられる。

$$
\mathrm{Nd}_{\mathrm{d}}=\mathrm{Pd} / \mathrm{qd} \cdot \mathrm{A}
$$

\section{2 原位置実験}

\section{2.1 実験概要}

実地盤中に細径鋼管（以下パイルと呼ぶ）を埋設した 後、実大寸法の布基礎の一部を模した鋼製載荷板を地盤 上に設置し、これを段階的に加力する方法と、パイルの みを段階的に加力する方法により原位置載荷実験を行っ た。この実験の目的は、室内実験によって明らかとなっ た基礎の沈下挙動と地盤の支持力特性、パイルと地盤と

表7 実験の種類

\begin{tabular}{|c|c|c|}
\hline 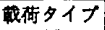 & 内 & 俏考 \\
\hline A & パイル(1本)のみ & 0 \\
\hline B & パイル(2本)+戟侍板 & $\delta^{450}{ }^{4}$ \\
\hline c & 板荷板のみ & $L_{650-t}$ \\
\hline
\end{tabular}

表8 実験ケースと実験条件

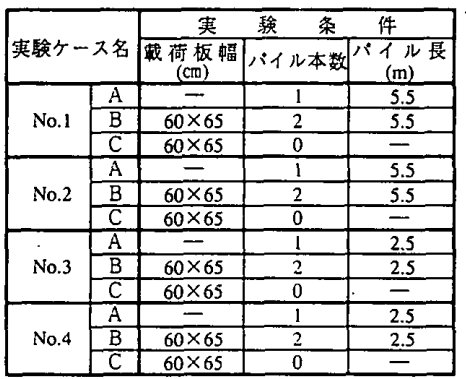

の荷重分担特性などを実地盤において確認するととも に、補強地盤の長期許容支持力度の目標值 $5 \mathrm{tf} / \mathrm{m}^{2}$ 以上を 確認することにある。

（1）実験の種類と地盤性状

4 ヶ所の地盤において表7に示す3種類の載荷実験を
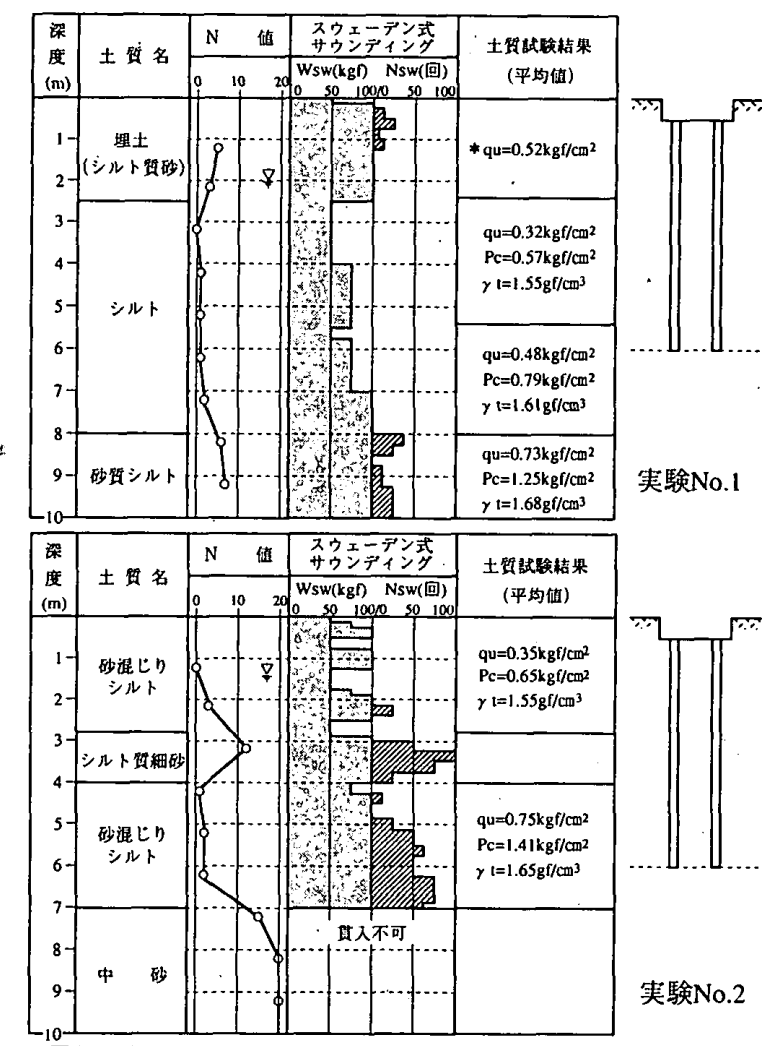

実験No.2

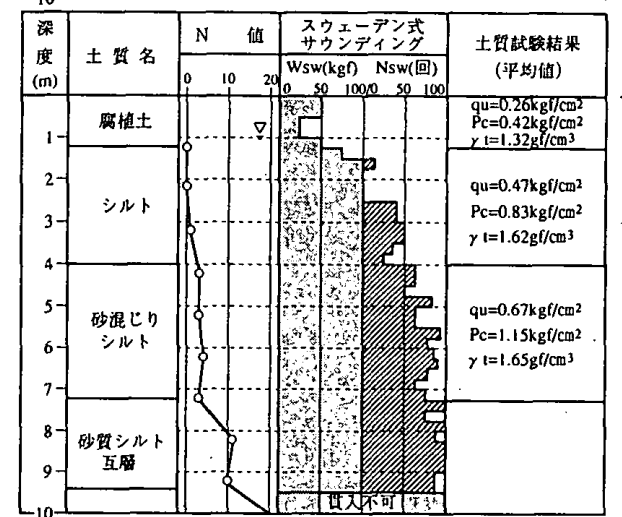

奏験No.3

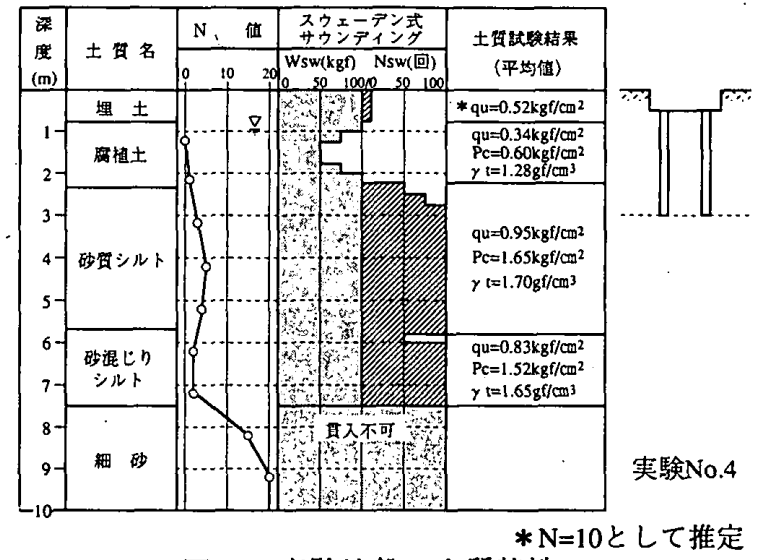

図18 実験地盤の土質特性 
行った。表8に実験ケース名と実験条件を、図18に各地 盤の土質柱状図、スウェーデン式サウンディング結果お よび土質試験結果を示す。同図中にはパイルの設置深度 も示してある。なお、いずれの地盤も、スウェーデン式 サウンティングを2斦、ボーリング（サンプリングを含 む）を1ケ所で実施したが、No.1とNo.4の埋土層について は土質特性と層厚に、かなりのばらつきが認められた。

（2） パイルの仕様と設置方法

実験には表1に示す仕様のパイルを用いた。タイプB の実験に用いたパイルの頭部内面には杭頭軸力を测定す るためのひずみゲージが貼付されている。

パイルの設置は、まず、パイル先端部に地盤への貫入 を容易にするためのコーンを嵌合した後、パイルを電動 モーターの回転力と自重（800kgf）により所定の深度ま で貫入させる方法によって行った。なお、パイル設置か ら2週間以上経過した後、載荷実験を行った。

（3）載荷実験装直と載荷・計測方法

載荷実験には図19に示す装置を用い、載荷方法、荷重 の移行、計測項目、計測方法、沈下量の計測時間などは 土質工学会編「地盤の平板載荷試験法」 ${ }^{13)}$ 、「クイの鉛 直載荷試験基準」14)に準拠した。

荷重の計測にはプルービングリング式荷重計、沈下量

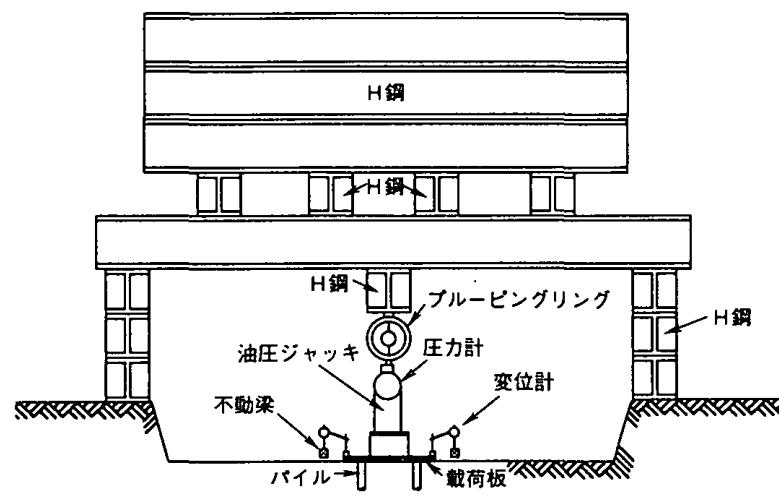

図19載荷実験装置

表9 $\mathrm{p}_{\mathrm{y}},\left(\mathrm{p}_{\mathrm{yA}} / \mathrm{p}_{\mathrm{yC}}\right),\left(\mathrm{p}_{\mathrm{yB}} / \mathrm{p}_{\mathrm{yC}}\right)$, および, ( $\mathrm{p}$ yB/p yAC)の比較表

\begin{tabular}{|c|c|c|c|c|c|}
\hline \multicolumn{2}{|c|}{ 実験ケース名 } & py & pyA & pys & рув \\
\hline \multirow{3}{*}{ No.1 } & A & 6.5 & \multirow{3}{*}{0.92} & \multirow{3}{*}{1.81} & \multirow{3}{*}{0.94} \\
\hline & B & 12.9 & & & \\
\hline & C & 7.1 & & & \\
\hline \multirow{3}{*}{ No.2 } & A & 8.9 & \multirow{3}{*}{1.53} & \multirow{3}{*}{2.10} & \multirow{3}{*}{0.82} \\
\hline & B & 12.2 & & & \\
\hline & $\mathrm{C}$ & 5.8 & & & \\
\hline \multirow{3}{*}{ No.3 } & $\mathrm{A}$ & 7.4 & \multirow{3}{*}{1.12} & \multirow{3}{*}{1.84} & \multirow{3}{*}{0.86} \\
\hline & B & 12.1 & & & \\
\hline & $\mathrm{C}$ & 6.6 & & & \\
\hline \multirow{3}{*}{ No.4 } & A & 8.6 & \multirow{3}{*}{0.84} & \multirow{3}{*}{1.20} & \multirow{3}{*}{0.65} \\
\hline & B & 12.2 & & & \\
\hline & $\mathrm{C}$ & 10.2 & & & \\
\hline
\end{tabular}

の計測には摺動抵抗型変位計を使用した。沈下量の計測 位置は、タイプ A がパイル頭部1ケ所、タイプ B,Cが載

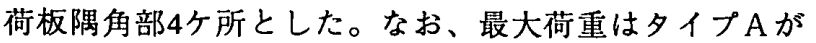
2tf、タイプB,Cが6tfとした。

\section{2.2 載荷実倹結果}

図20に荷重度一沈下量関係を示す。ただし、Aは載荷 タイプA（パイル1本）の荷重－沈下量関係の荷重を 2 倍してパイル2本分に換算し、更に、この荷重をタイプ B，Cの載荷板の面積で除して荷重度とした結果を表し ている。 $\log \mathrm{p}-\operatorname{logs}$ 関係より求めた降伏荷重度 p y、タイプ

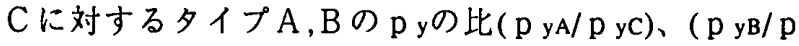

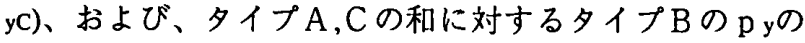
比( p yB/p yAC)を表9に示す。また、図21に同一沈下レべ ルにおけるタイプCに対するタイプ Bの荷重度の比(荷 重増加率: $\mathrm{p} \mathrm{B} / \mathrm{p} \mathrm{c}$ ) と沈下量との関係を、図22にタイプC に対するタイプ Bの沈下低減率(1-SB/SC)と荷重度との関 係を示す。一方、図23に、タイプBについて、パイルと 地盤との荷重分担比 $N\left(\mathrm{P}_{\mathrm{p}} / \mathrm{P} \mathrm{G}_{\mathrm{G}}\right)$ と荷重度との関係を示 す。ただ、 $P_{p}$ は杭頭部の軸力、 $P$ G は載荷荷重 $P$ と $P p$ との差(= P-PG) を表している。

これらの図表より、以下の点が明らかとなった。 1)タイプCの降伏荷重度 $\mathrm{p}$ yは約6〜 10t $/ \mathrm{m}^{2}$ であるのに対 し、タイプ Bの $\mathrm{p}_{\mathrm{y}}$ は $12 \sim 13 \mathrm{tf} / \mathrm{m}^{2}$ を示しており、 $\mathrm{p}$ の $1 / 2$ を長期許容支持力度とすれば、タイプ Bではいずれも $5 \mathrm{tf} / \mathrm{m}^{2}$ 以上の長期許容支持力度が得られている。

2)いずれの実験とも、タイプ Bの p yはタイプ A,Cの p y の和より小さくなる。

3)パイルによる沈下低減率、荷重増加率、荷重分担比 は、タイプCの $\mathrm{p} y$ に対するタイプ $\mathrm{A} の \mathrm{p}_{\mathrm{y}}$ の比( $\left.\mathrm{p} \mathrm{yA} / \mathrm{p} \mathrm{yC}\right)$
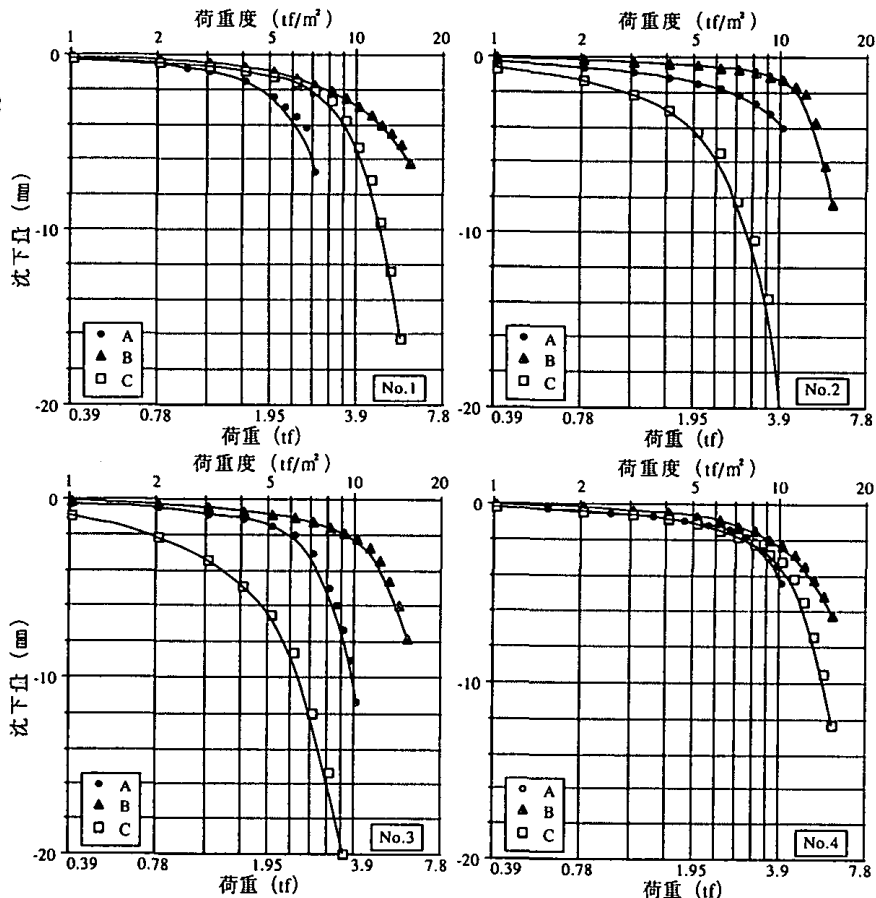

図20 荷重度一沈下量関係 


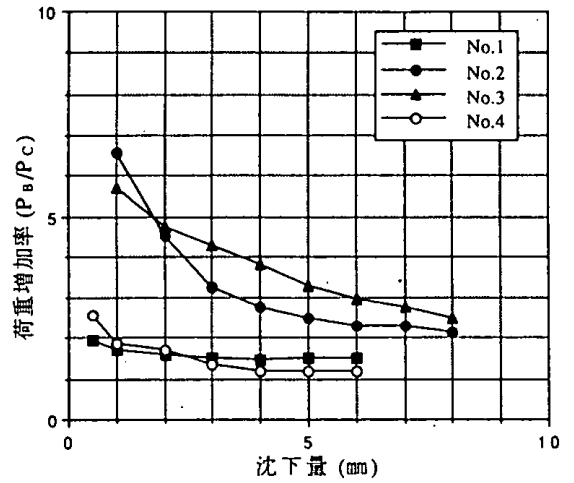

図21 荷重増加率－沈下量関係

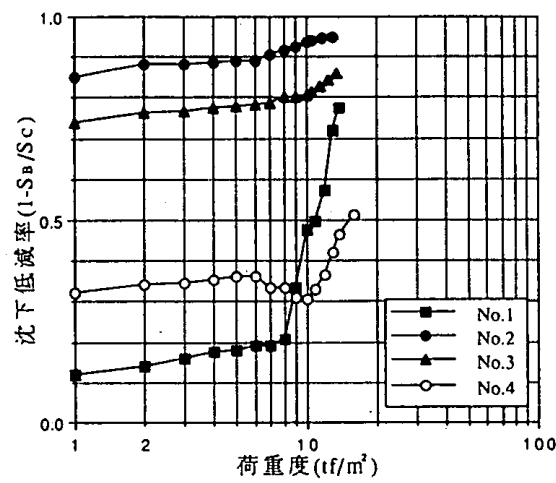

図22 沈下低減率一荷重関係

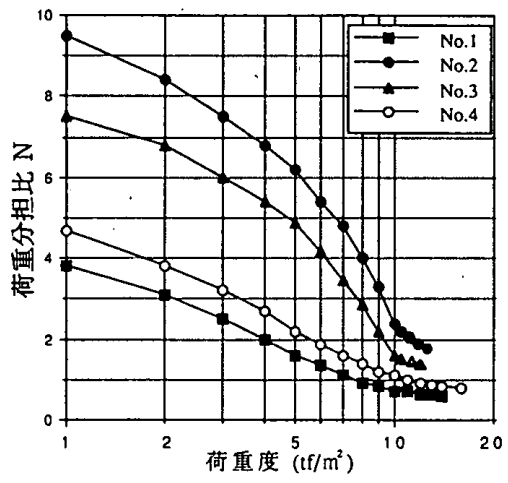

図23 荷重分担比一荷重度関係
が大きいほど高くなる傾向を示す。因みに、設計荷重レ ベル $\left(5 \mathrm{tf} / \mathrm{m}^{2}\right)$ での沈下低減率は、( $\left.\mathrm{p} \mathrm{yA} / \mathrm{p} \mathrm{yc}\right)$ が 1 以下と なるNo.1,No.4で0.18〜0.36、( p yA/p yc)が2前後となる No.2,No.3で0.78〜0.88となり、沈下低隇効果に著しい差 が認められる。

4)パイルによる荷重増加率、荷重分担比は、沈下の進行 あるいは荷重度の増加とともに低下し、最終的にはある 一定值に収れんする傾向にある。

5)パイルによる沈下低減率は、荷重度とともに増加す る。特に、No.2,No.3に比較して沈下低減効果の小さい No.1,No.4については、降伏荷重を越えた荷重領域で急激 に増加する。

\section{2 . 3 実験結果に対する考察}

(1) パイルの設置効果

パイルによる沈下低減率、荷重増加率、荷重分担比

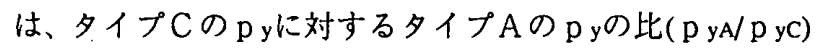
が大きいほど高くなる傾向を示している。

原位置載荷実験では、反力の都合上、全ヶースについ て極限支持力を確認できたわけではないが、( $\mathrm{p} \mathrm{yA} / \mathrm{p} \mathrm{yc})$ が大きいほどタイプCの極限支持力に対するタイプAの 極限支持力の比 $\left(\mathrm{quA}_{\mathrm{u} / \mathrm{quC}}\right)$ も大きくなると予想されるの で、多層地盤においても室内模型実験での均一地盤の場 合と同様、パイルによる沈下低減率、支持力増加率、荷 重分担比は、( p uA/ p uc)が大きいほど高くなると考える ことができる。

一方、3.1.3(2)で推察した如く、表層がその直下の土層 より硬い場合(No.1,No.4)にはパイルの設置効果は小さ く、逆に、表層がその直下の土層より軟らかく、かつ、 パイル先端付近の土層がその上部より硬い場合 (No.2,No.3)にはパイルの設置効果が大きくなることが確 認された。すなわち、図16に示したタイプA,Bのパイル と地盤との相対変位の相違により、パイル頭部付近より パイル先端部の土層が硬い地盤の方が、パイル先端支持 力や摩擦力が有効に発揮され、その設置効果は高くな る。また、図22によるとに、降伏荷重以前に沈下低減効 果の小さかったNo.1,No.4についても降伏荷重以降、すな
わち、沈下が急増する荷重以降において沈下低減効果も 急増することから、沈下の増加とともにパイル周面摩擦 力が有効に発揮される範囲は次第に上方に移行すると考 えられる。

\section{（2）補強地盤の支持力}

タイプ Bの $\mathrm{p}$ yがタイプ $\mathrm{A}, \mathrm{C}$ の $\mathrm{p}$ yの和より小さくなる 現象は室内実験と同様な傾向であり、タイプ Bの長期許 容支持力度(降伏荷重度の $1 / 2$ )をタイプ A, C 各々の長期許 容支持力度(降伏荷重度の $1 / 2$ )の和として算出すると、補 強地盤の長期許容支持力度を奏状より過大評価すること. が、実地盤においても確認された。

一方、今回の実験では、極限支持力度を確認できな かったことや、各タイプの地盤性状にばらつきがあった ことから、タイプ Bの極限支持力度がタイプ A,Cの極 限支持力度の和として近似できるか否かを確認するには 至らなかった。しかし、タイプA，Cがほほ極限状態ま で載荷されたNo.1,No.3に着目する.と、タイプ Bの p yを3/ 2倍した值注1)とタイプ A,Cの最大荷重の和が比較的良 く対応する。したがって、各タイプの地盤にばらつきが なく、かつ、極限状態まで載荷すれば、タイプ Bの極限 支持力度はタイプ $\mathrm{A}, \mathrm{C}$ の極限支持力度の和に近似する ものと考えられる。

なお、地盤条件やパイル長さの異なる4 所の載荷実 験により、タイプ Bではいずれも $5 \mathrm{tf} / \mathrm{m}^{2}$ 以上の長期許容 支持力度が得られたことから、表1の仕様のパイルを基 礎スラブ面積 $0.39 \mathrm{~m}^{2}(0.60 \times 0.65 \mathrm{~m})$ 当り 2 本設置し、かつ、 パイル1本当りの極限支持力を $1.5 \mathrm{tf}$ 以上確保できれば、 $3 \mathrm{tf} / \mathrm{m}^{2}$ 程度であった地盤の長期許容支持力度を $5 \mathrm{tf} / \mathrm{m}^{2}$ 以上 にできることが確認された。

\section{4. 補強地盤の長期許容支持力度推定法}

\section{1 長期許容支持力度推定法の提案}

補強地盤の極限支持力度 q raは、パイルを設置してい ない地盤（以下未補強地盤とよぶ）の極限支持力度 q d とパイルの極限支持力度 $\mathrm{Pd} / \mathrm{A}$ との和、すなわち、式(1) 
により近似することが可能と考えられる。

これに対し、補強地盤の降伏荷重度 q ryは未補強地盤 とパイルの降伏荷重度 $\mathrm{q}$ y, $\mathrm{P}$ y/Aの和より小さくなり、当 然、q ryの1/2を長期許容支持力度とした q raについても 同様な結果になる。これは、パイルと地盤との荷重分 担比 Nが荷重レベル（または沈下レベル）により著しく 異なることに起因している。すなわち、補強地盤の支持 カに対するパイルと地盤の支持力の貢献度は荷重レベル により異なる。この点を考慮すると、式(1)の右辺の第 1 項（=qd） と第 2 項（=Pd/A） とを同じ安全率Fsで除 した式(3)を用いて q raを算定するより、 $\mathrm{qd}$ と $\mathrm{Pd} / \mathrm{A}$ に対 して異なった比率（部分安全率に相当する係数）を設定 した式(4)により q raを算定するのがより実状に合った方 法と考えられる。この方法は、杭の許容鉛直支持力を算 定する祭に、杭先端の極限抵抗力と杭周面の極限摩擦抵 抗力との奇与する割合を考虑する方法 ${ }^{15)}$ とほほ同一の考 え方に基づいている。

$$
\begin{aligned}
& \mathrm{q} \mathrm{ra}_{\mathrm{a}}=\mathrm{q} \mathrm{d} / \mathrm{Fs}+\left(\mathrm{Pd}_{\mathrm{d} / \mathrm{A}) / \mathrm{Fs}}\right. \\
& \mathrm{q} \mathbf{r a}=\mathrm{q}_{\mathrm{d}} / \mathrm{Fs} 1+\left(\mathrm{Pd}_{\mathrm{d}} / \mathrm{A}\right) / \mathrm{Fs} 2
\end{aligned}
$$

式 (4)のFs1、Fs2を求める当たり、極限状態の荷重分担 比 $\mathrm{Nd}$ に対する任意の荷重レベルでの $\mathrm{N}$ の比（= $\mathrm{N} / \mathrm{N}_{\mathrm{d}} ）$ を $\beta$ とすれば、実験結果より $\mathrm{N}_{\mathrm{d}} \leqq \mathrm{N}$ 、すなわち、 $1 \leqq$ $\beta$ となる。また、補強地盤を載荷板により加力した場合 には地盤部分よりパイルの方が低荷重領域で降伏し、か つ、同一荷重で未補強地盤と補強地盤とを加力した場合 には、地盤が直接分担する荷重は当然前者の方が大きく

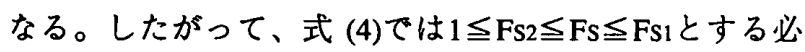
要がある。ここで、パラメー夕 $\mathrm{m} と \beta$ を用いて、Fs1,Fs2

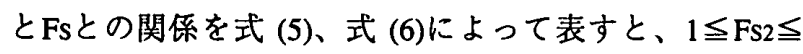
$\mathrm{Fs} \leqq \mathrm{Fs}_{1}$ の条件を満足させることが可能となる。ただ し、 $0 \leqq \mathrm{~m}$ とし、 $\mathrm{m}=0$ または $\beta=1$ の条件は、常に $\mathrm{N}=\mathrm{Nd}$ となることを意味し、Fs1=Fs2=Fsとなる。また、 $\beta=$ $\infty$ の条件ではFs $1=\infty 、 F S 2=1$ となる。式(5),(6)のFs 1 、 Fs2を式(4)に代入すると、qra式(7)によって表すこと ができる。

$$
\begin{aligned}
& \mathrm{Fs} 1=\mathrm{Fs}^{\beta^{\mathrm{m}}} \\
& \mathrm{Fs} 2=\mathrm{Fs}^{(1 / \beta)^{\mathrm{m}}} \\
& \mathrm{qra}=\mathrm{qd} / \mathrm{Fs}^{\beta^{\mathrm{m}}}+(\mathrm{Pd} / \mathrm{A}) / \mathrm{Fs}^{(1 / \beta)^{\mathrm{m}}}
\end{aligned}
$$

\section{4. $2 F s$ 値およびFs2值の試算}

通常、地盤の長期許容支持力度 $q$ a は極限支持力度 $q d$

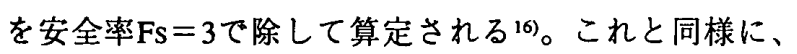

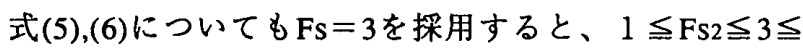
Fs1となる。すなわち、補強地盤の長期許容支持力度の うち、地盤部分とパイルの分担率 1/Fs1、1/Fs2は、各々 の極限支持力に対して、前者が 0 ～1/3、後者が $1 / 3 \sim 1$ と なる。図24は、Fs $=3$ とした場合の許容支持力分担率 1 /

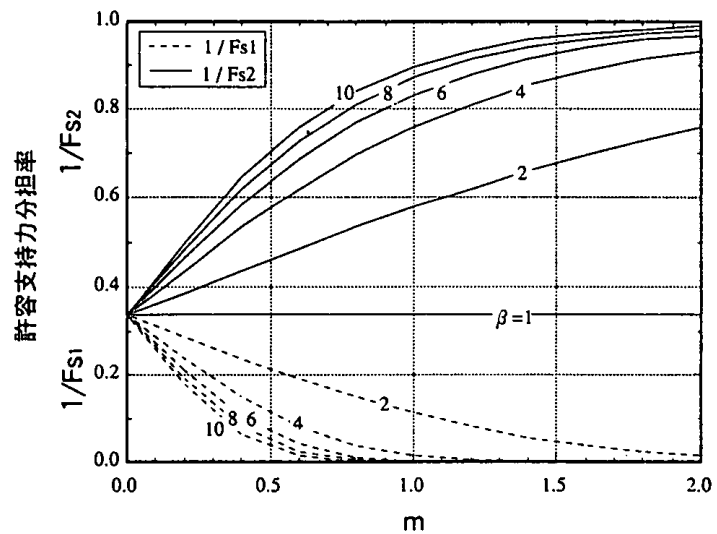

図24 Fs=3とした場合の許容支持力分担率 $1 / F s 1,1 / F s 2$

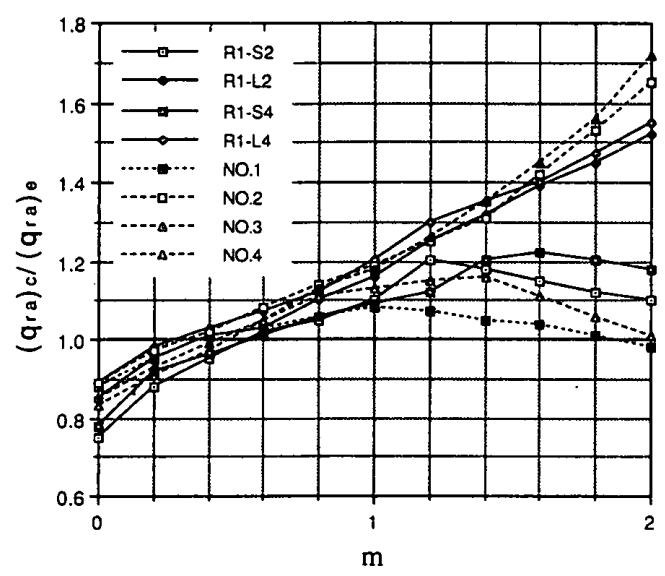

図25（q ra)c/( q ra)eと mとの関係

$\mathrm{Fs} 1 、 1 / \mathrm{Fs} 2$ と $\mathrm{m}$ との関係を、 $\beta$ をパラメータとして示し たものである。同図より、 $\mathrm{m}=0$ の場合には $1 / \mathrm{Fs} 1=1 / \mathrm{Fs} 2$ $=1 / 3$ となるが、mの増加に伴い、前者は 1 に漸近し、後 者は0漸近にすることがわかる。したがって、Fs1,Fs2を 決定するためにはmと $\beta$ を同定する必要がある。

そこでまず、室内載荷実験と原位置載荷実験によって 得られた補強地盤の降伏荷重度 $\mathrm{q} y$ の $1 / 2$ を長期許容支持 力度( q ra)eとし、(q ra)e付近の荷重レベルにおける $\beta(=$ $\mathrm{N} / \mathrm{Nd}$ )を求めると、実験条件によりばらつきがあるもの の、ほほ $2<\beta<4$ 、平均的には $\beta \fallingdotseq 3$ となる。

次に、載荷実験によって得られた末対策地盤とパイル の降伏荷重度 q y, $\mathrm{P} y / \mathrm{A}$ の3/2倍を各々の極限支持力度 $\mathrm{q} \mathrm{d}$, $\mathrm{Pd} / \mathrm{A}$ と仮定し、Fs=3、 $\beta=3 、 0 \leqq \mathrm{~m} \leqq 2$ の場合につい て、 $\mathrm{qd}, \mathrm{Pd} / \mathrm{A}$ を式(7)に代入して補強地盤の長期許容支持

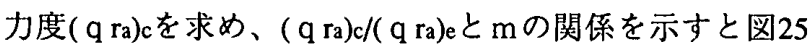

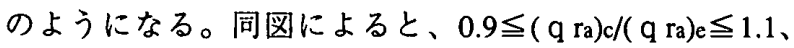
すなわち、( q ra $)_{c}$ と ( q ra $)_{\mathrm{e}}$ とが $10 \%$ 程度の誤差範囲内とな る $\mathrm{m}$ の領域はほほ $0.2<\mathrm{m}<0.6$ となる。この領域におけ るFs1、Fs2 の值は、式(5),(6)より各々4.0〜8.0,1.8〜2.4と なる。特に、ばらつきの少ない室内実験結果によると、 各々の平均值は5および2前後となる。したがって、q ra をほぼ式(8)のように表すことができる。 


$$
\mathrm{q} r \mathrm{a} \doteqdot \mathrm{qd} / 5+(\mathrm{Pd} / \mathrm{A}) / 2
$$

$\mathrm{m} 、 \beta$ 共にかなりの幅があることから、式(8)によって 求めた q ra誤差も地盤条件やパイルの設置条件により かなり異なると考えられるが、この考え方を拡張すれ ば、パイルと地盤の各々の降伏荷重度から補強地盤の長 期許容支持力度を推定することも可能になると考えられ る。

\section{5. 結論}

本論文では、細径鋼管（以下パイルとよぶ）により補 強した地盤上の基礎の沈下挙動と地盤の支持力特性を、 室内載荷実験と原位置載荷実験の結果に基づいて検討 し、更に、補強地盤の長期許容支持力度推定法を提案し た。本論文の結論を紷括的に示すと以下のようになる。 1)基礎直下の地盤をパイルで補強することにより、基䃈 の沈下量を低減させ、補強地盤の支持力を增加させるこ とができる。沈下低減効果、支持力増加効果は未補強地 盤の極限支持力度に対するパイルの極限支持力度（パイ ルの極限支持力を支配面積で除した值）の比が大きいほ ど著しい。

2)パイルのみ載荷した場合とパイルを設置した基礎を載 荷した場合とでは、パイルの深さ方向の周面摩擦力分布 に著しい違いが生じる。すなわち、前者ではパイル全長 にわたって摩擦力がほほ均等に発揮されるのに対し、後 者ではパイル先端はど有効に発揮される。この原因は、 パイルと地盤との相対変位の違いによるものである。し たがって、表層部よりパイル先端付近の土層が硬い地盤 の方がパイル設置の効果は大きい。

3)補強地盤の極限荷重度をパイルと未補強地盤の極限荷 重度の和によって近似できても、補強地盤の降伏荷重度 をパイルと末補強地盤の降伏荷重度の和によって近似す ることはできない。これは、地盤が直接分担する荷重と パイルが分担する荷重の比が荷重レベル（または沈下レ ベル）により著しく異なることに起因している。

4)直径48.6mmのパイルを基礎スラブ面積 $0.39 \mathrm{~m}^{2} \quad(0.60 \mathrm{~m} \times$ $0.65 \mathrm{~m})$ 当り 2 本設置し、かつ、パイル1本当りの極限支持力 を $1.5 \mathrm{tf}$ 以上確保できれば、 $3 \mathrm{tf} / \mathrm{m}^{2}$ 程度であった地盤の長期 許容支持力度を $5 \mathrm{tf} / \mathrm{m}^{2}$ 以上に高めることが可能である。 5)通常、地盤の長期許容支持力度は極限支持力度を安全 率Fs $(=3)$ 、または、降伏荷重度を安全率Fs $(=2)$ で除して 算定されるが、補強地盤の長期許容支持力度について は、パイルと地盤との荷重分担比、あるいは、各々の沈 下性状を考虑すると、未補強地盤とパイルの極限支持力 度（または降伏荷重度）を同一の安全率Fsで除して算定 するより、未補強地盤の極限支持力度（または降伏荷重 度）をFs以上の值(Fs1)、パイルの極限支持力度（または 降伏荷重度) をFs以下の值(Fs2)で除した值の和によって
算出した方が適当と考えられる。因みに、室内載荷実験 によると、極限支持力度に対してはFs $1 \doteqdot 5 、 F s 2 \doteqdot 2$ と なった。

\section{6. あとがき}

本論文では、基礎スラブ直下の地盤に細径鋼管を1本 および2本設置した場合の基礎の沈下挙動と補強地盤の 支持力特性について述べたが、本工法を低層建物に適用 する場合には、図1に示した如く、布基礎直下に多数の 細径鋼管が設置される。このような条件での、基礎の長 期的な沈下挙動と補強地盤の支持力特性を調査するため の原位置載荷実験も実施している。

そこで、第2報では、上記実験結果について述べると 共に、補強地盤一基礎系の沈下予測法とこの予測法を用 いた実測沈下量のシミュレーション解析結果について報 告する予定である。

終りに、原位置実験を実施するにあたり、多大なご支 援を頂いた大成建設(侏)住宅事業本部の関係各位に感謝の 意を表します。

\section{参考文献}

1) 特集 低層・戸建住宅の基䃈、基碟工 Vol. 15,No. 7,pp.2 95,1987

2) 特集 住宅の基礎(戸建住宅の基礎)、基礎工 Vol. 20,No. 12, pp.2 298,1992

3) 岩尾ほか：有明粘土地盤における住宅基䃈実大載荷実験、 土と基礎、Vol.34,No.6,pp.29〜35,1985

4)安川ほか：軟弱地盤におけるこま型基礎の支持特性、第32回土質工 学シンボ ジウム発表論文集、pp.49〜54,1987

5) 佐藤ほか：超軟弱地盤における小規模建物用基礎の載荷実験、 第27回土質工学研究発表会講演集、pp. 1707 1708,1992

6) 若命善雄：特集・日本建築センター評定工法設計事例 1984年、 RES工法による低層建物基礎の設計・施工例、基礎工 Vol. 13， No. 12,pp.80 85,1985

7) 若命善雄、真島正人：複合地盤の支持力機構に関する実験的研究 (その1),(その2),(その3),(その4), 第 17,18,19,20回土質工学会研究発 表会、1982,1983,1984,1985

8) J.B.Burland et al. : Behavior of foundation and structures, Proc. of 9th ICSMFE, Vol.2 pp495 506, Tokyo, 1977

9) 加倉井ほか：沈下抑止杭を用いた併用基礎の設計と実測、 20 回土質工学会研究発表会、pp1173 1174, 1986

10）角ほか：フローフィング基礎と杭を併用した建物の挙動 (その3 - 長期計測結果)，日本建築学会大会学術講演梗概集、 pp1457 1458, 1989

11）渡井ほか：麼擦杭を併用した直接基䃈の挙動（その 5 - 軟弱沖樻 層地盤における実測例），日本建築学会大会学術講演梗概集、 pp1455 1456, 1989

12) 光成ほか：特殊石灰パイルによる複合地盤の載荷実験 （その2）、27回土質工学会研究発表会、pp1465 1466, 1992

13) 土質工学会：地盤の平板載荷試験方法、同解説, 1983.1

14) 土質工学会：クイの鉛直載荷試験基準、同解説, 1971

15) 日本建築学会：建築基碟構造設計指針、pp217～220,1988

16）日本建築学会：建築基礎構造設計指針、pp119～120,1988

\section{注}

注1)タイプBについては、極限状態まで載荷されていないため、極限 荷重度の概略値を p yの3/2倍として推定した。

（1993 年 5 月 10 日原稿受理，1993 年 10 月 27 日採用決定） 